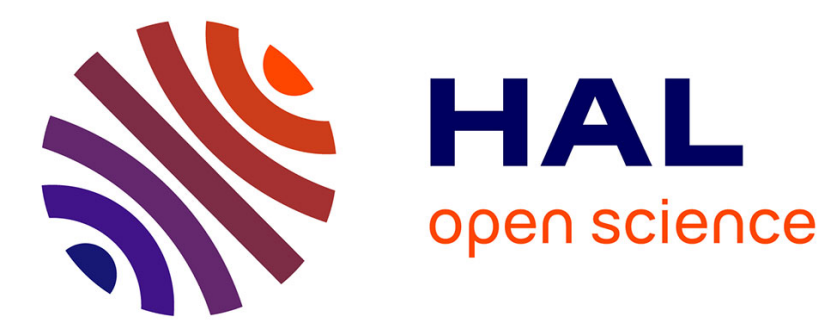

\title{
Supramolecular self-assembly of brominated molecules on a silicon surface
}

Younes Makoudi, Matthieu Beyer, Judicaël Jeannoutot, Fabien Picaud, Frank Palmino, Frédéric Cherioux

\section{To cite this version:}

Younes Makoudi, Matthieu Beyer, Judicaël Jeannoutot, Fabien Picaud, Frank Palmino, et al.. Supramolecular self-assembly of brominated molecules on a silicon surface. Chemical Communications, 2014, 50 (43), pp.5714 - 5716. 10.1039/C4CC01158A . hal-03222012

\section{HAL Id: hal-03222012 \\ https://hal.science/hal-03222012}

Submitted on 10 May 2021

HAL is a multi-disciplinary open access archive for the deposit and dissemination of scientific research documents, whether they are published or not. The documents may come from teaching and research institutions in France or abroad, or from public or private research centers.
L'archive ouverte pluridisciplinaire HAL, est destinée au dépôt et à la diffusion de documents scientifiques de niveau recherche, publiés ou non, émanant des établissements d'enseignement et de recherche français ou étrangers, des laboratoires publics ou privés. 
archives-ouvertes

\title{
Supramolecular self-assembly of brominated molecules on a silicon surface
}

\author{
Younes Makoudi, Matthieu Beyer, Judicaël Jeannoutot, Fabien Picaud, Frank \\ Palmino, Frédéric Cherioux
}

\section{To cite this version:}

Younes Makoudi, Matthieu Beyer, Judicaël Jeannoutot, Fabien Picaud, Frank Palmino, et al.. Supramolecular self-assembly of brominated molecules on a silicon surface. Chemical Communications, Royal Society of Chemistry, 2014, 50 (43), pp.5714 - 5716. 10.1039/C4CC01158A . hal-03222012

\section{HAL Id: hal-03222012 \\ https://hal.archives-ouvertes.fr/hal-03222012}

Submitted on 10 May 2021

HAL is a multi-disciplinary open access archive for the deposit and dissemination of scientific research documents, whether they are published or not. The documents may come from teaching and research institutions in France or abroad, or from public or private research centers.
L'archive ouverte pluridisciplinaire HAL, est destinée au dépôt et à la diffusion de documents scientifiques de niveau recherche, publiés ou non, émanant des établissements d'enseignement et de recherche français ou étrangers, des laboratoires publics ou privés. 


\title{
Supramolecular self-assembly of brominated molecules on a silicon surface $\dagger$
}

\author{
Y. Makoudi, ${ }^{a}$ M. Beyer, ${ }^{a}$ J. Jeannoutot, ${ }^{a}$ F. Picaud, ${ }^{b}$ F. Palmino ${ }^{a}$ and F. Chérioux ${ }^{* a}$
}

Received 13th February 2014,

Accepted 30th March 2014

DOI: $10.1039 / c 4 c c 01158 a$

www.rsc.org/chemcomm

Hydrogen and halogen bonds have been associated for the growth of 2D compact supramolecular networks on a silicon surface. These interactions have been elucidated in a complete monolayer of a $4,4^{\prime \prime}$-dibromo-p-terphenyl (DBT) molecule on a Si(111)-B surface by combining scanning tunneling microscopy (STM) and density functional theory (DFT) calculations.

In nanoscience and nanotechnology, self-assembly has become a powerful method to achieve the design and fabrication of nanostructures at the nanometer scale. ${ }^{1}$ Supramolecular chemistry deals with the non-covalent intermolecular interactions to create highly ordered structures by self-assembling tailored building blocks. ${ }^{2}$ Since the pioneering studies, the basic rules of supramolecular chemistry have been extended to promote the formation of 2D supramolecular networks on a surface. The amount of noncovalent interactions is wide to successfully achieve the formation of periodic, large-scaled 2D networks: van der Waals interactions, hydrogen bonds, metal-organic bonds, electrostatic interactions etc. ${ }^{3}$ More recently, the halogen bond (i.e. between two halogen atoms) has emerged as one of the most exciting noncovalent interactions ${ }^{4}$ due to its directionality, its tunability and its hydrophobicity compared to the other noncovalent interactions like hydrogen bonds. 2D networks based on halogen bonds are now currently reported on noble metal or HOPG surfaces. ${ }^{5}$ However, this large-scaled 2D supramolecular assembly in which a halogen bond acts as a driving force has not yet been demonstrated on a silicon surface. Indeed, on this surface, when a halogenated molecule is deposited, the competition between the Molecule-Molecule (MM) and the Molecule-Substrate (MS) interactions is very severe and often turns out in favour of the substrate. ${ }^{6}$ Here, we proposed to investigate the adsorption under

\footnotetext{
${ }^{a}$ Institut FEMTO-ST, Université de Franche-Comté, CNRS, ENSMM,

32 Avenue de l'Observatoire, F-25044 Besancon, France.

E-mail: frederic.cherioux@femto-st.fr

${ }^{b}$ Laboratoire de Nanomédecine, Imagerie et Thérapeutiques,

Université de Franche-Comté, 12 route de Gray, F-25030 Besancon, France

$\dagger$ Electronic supplementary information (ESI) available: Si(111)-B preparation,

STM experiments and computational details. See DOI: $10.1039 / \mathrm{c} 4 \mathrm{cc} 01158 \mathrm{a}$
}

ultra-high vacuum of a 4,4"-dibromo-p-terphenyl (DBT) molecule on a passivated silicon surface, the $\operatorname{Si}(111)-B$ surface. ${ }^{7}$ Under these conditions, the adsorption of DBT on the Si(111)-B surface leads to a 2D compact supramolecular network revealed by scanning tunneling microscopy (STM). The growth of this $2 \mathrm{D}$ network is proved to be driven by the association of hydrogen and halogen bonds, as demonstrated using density functional theory (DFT) calculations.

The DBT molecule is based on three phenyl rings ending with two bromine atoms. These bromine atoms are at a distance of $1.53 \mathrm{~nm}$ (see Fig. 1a). The adsorption of DBT on $\mathrm{Si}(111)-\mathrm{B}$ leads to the formation of large islands, covering at least an area of $200 \times 200 \mathrm{~nm}^{2}$ (see Fig. 1b and Fig. S1 in ESI $\dagger$ ).

a)

b)
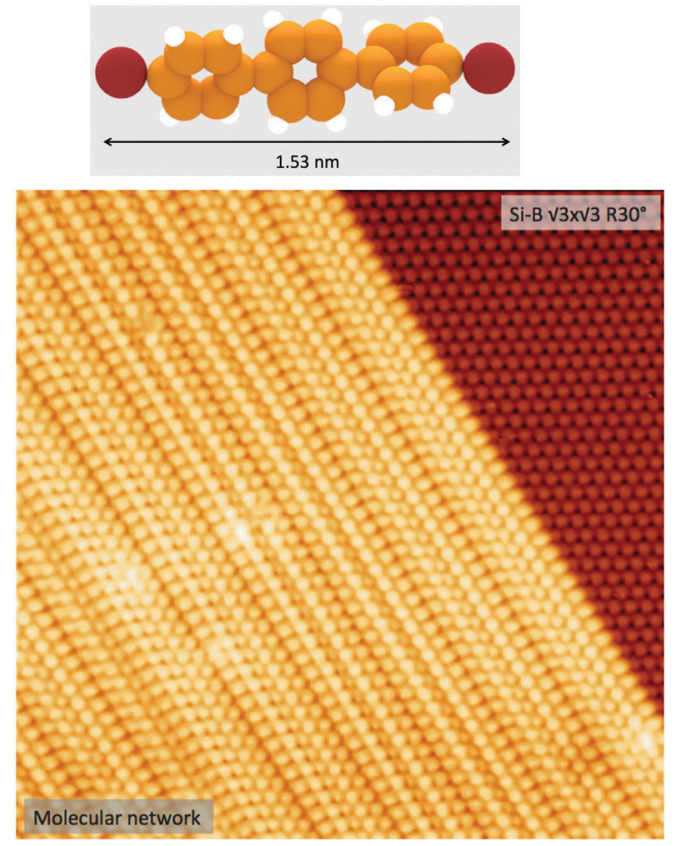

Fig. 1 (a) Chemical structure of a 4,4"-dibromo-p-terphenyl (DBT) molecule (orange: carbon atoms, white: hydrogen atoms and red: bromine atoms); (b) STM image $\left(V_{\mathrm{s}}=1.7 \mathrm{~V}, I_{\mathrm{t}}=10 \mathrm{pA}, 29 \times 29 \mathrm{~nm}^{2}, 100 \mathrm{~K}\right)$ of the DBT network on a $\mathrm{Si}(111)-\mathrm{B}$ surface. 


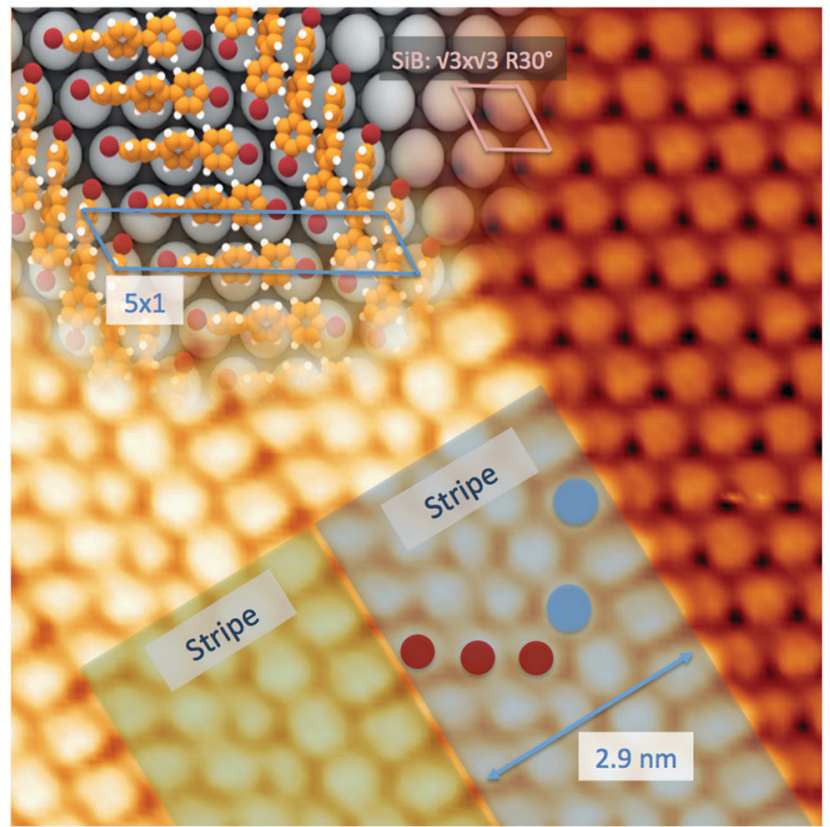

Fig. 2 STM image of a step edge island of a commensurable monolayer of DBT on a Si(111)-B surface. The molecular adsorption model is superimposed on the upper part of the image $\left(V_{\mathrm{s}}=+1.7 \mathrm{~V}, I_{\mathrm{t}}=10 \mathrm{pA}, 10 \times\right.$ $\left.10 \mathrm{~nm}^{2}, 100 \mathrm{~K}\right)$. A DBT molecule is attributed to three red spots or to two blue spots, depending on its adsorption site.

These islands consist of 2D compact networks without defects, which can be seen as large parallel stripes (see Fig. 2) with a width of $2.9 \mathrm{~nm}$. The periodicity of the organic network is $5 \times 1$ and the network forms a commensurable structure with the $\sqrt{ } 3 \times \sqrt{ } 3$ reconstruction of the $\operatorname{Si}(111)$-B surface (see Fig. 2). This structure is described by five bright protrusions. Among these five protrusions, three of them (red spots) are slightly smaller and are aligned. The other two (blue spots) are larger and are oriented at $95 \pm 5^{\circ}$ relative to the first three (see Fig. 2).

Given the dimensions of a DBT molecule in the gas phase and assuming that the shape of DBT is not strongly altered after adsorption of the molecule, we are able to identify individual molecules in the network. These features indicate that there are two molecules per unit cell with two molecular orientations. The first DBT molecule is adsorbed on three aligned silicon adatoms (corresponding to three red spots in Fig. 2). Three small protrusions are attributed to this DBT molecule. These two bromophenyl groups and the central phenyl are exactly located above three silicon adatoms (see Fig. 2). The two bromophenyl groups of the second DBT molecule are adsorbed on two silicon adatoms of the main diagonal of the $\sqrt{ } 3 \times \sqrt{3}$ reconstruction (see blue spots in Fig. 2). These two large protrusions are attributed to the second DBT molecule. In order to understand the formation of the supramolecular DBT/Si(111)-B network, MM interactions are detailed in the following paragraph.

In a stripe, two DBT molecules included in a unit cell interact by a halogen bond, between two bromine atoms ( $\mathrm{Br}-\mathrm{Br}$ distance: $0.45 \mathrm{~nm}$, see yellow arrows in Fig. 3) and by two unconventional hydrogen bonds (between a hydrogen atom and a bromine atom

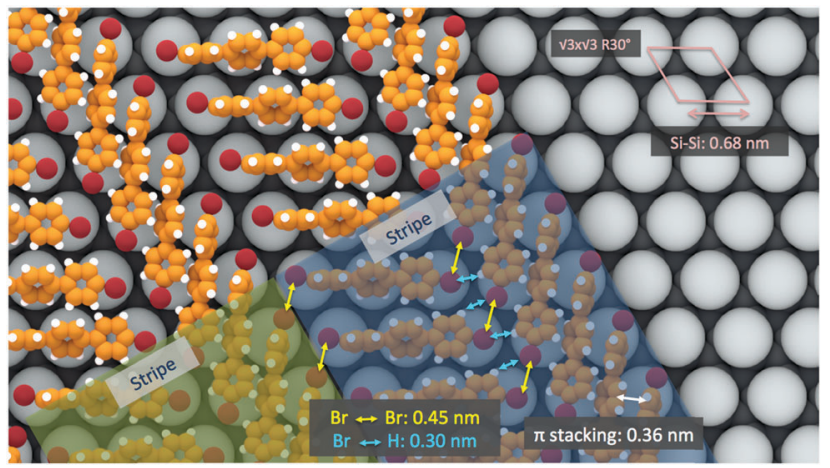

Fig. 3 Aryl-Br...H distance and aryl-Br...Br-aryl distances between two DBT molecules in an elemental cell of DBT/Si(111)-B evaluated from experimental STM images.

distanced by $0.30 \mathrm{~nm}$, see blue arrows in Fig. 3). Moreover, a $\pi$-stacking interaction occurs between DBT molecules adsorbed over two silicon adatoms due to a distance of $0.36 \mathrm{~nm}$ between two phenyl groups of two different molecules (see the white arrow in Fig. 3). However, between two different stripes, only the halogen bond is possible due to the bromophenyl group orientation, avoiding hydrogen bonds. This effect is highlighted by a darker line, separating all the stripes in STM images (Fig. 1b and 2). In addition, when a defect in the DBT/Si(111)-B network occurs, it can be observed as a lack of a stripe in STM images (see Fig. S2 and S3 in ESI $\dagger$ ). This effect shows that MM interaction inside a stripe is greater than MM interaction between two stripes.

To corroborate the experimental hypotheses relative to the structure adopted by the molecules on the $\mathrm{Si}(111)-\mathrm{B}$ surface, full DFT calculations at the B3LYP/6,311G* level of theory included in the Gaussian 09 (revision C.01) program package ${ }^{8}$ were investigated. The role of the intermolecular interactions has been studied by progressively building the molecular lattice in vacuum (see Simulation details in ESI $\dagger$ ). In order to estimate MM interaction, the geometry of two adjacent elemental cells has been optimized in the vacuum. The optimized structure leads to a strong MM interaction with an energy of $-842.3 \mathrm{meV}$. Indeed, in this configuration, the molecules can reinforce the number of halogen bonds while keeping $\pi-\pi$ stackings. The mean distance between each nearest $\mathrm{Br}$ atoms, involved in halogen bonds, becomes equal to $0.44 \pm 0.05 \mathrm{~nm}$, while each hydrogen bond presents a mean distance of $0.31 \pm 0.01 \mathrm{~nm}$ (see Simulation details in ESI $\dagger$ ), in quite well agreement with the proposed model (Fig. 3). The angle between two adjacent DBT molecules is $108 \pm 5^{\circ}$. The different contributions of MM interaction energy have been graded from DFT calculations (see $\mathrm{ESI} \dagger$ ). Hydrogen bond (i.e. $\mathrm{Br}-\mathrm{H}$ ) interactions account for $-72 \mathrm{meV}$ per bond while halogen bond (i.e. $\mathrm{Br}-\mathrm{Br}$ ) and $\pi$-stacking interactions lead to interaction equal to $-15 \mathrm{meV}$ (respectively $-14 \mathrm{meV}$ ). Hydrogen bonds seem to be the strongest driving force for the formation of the supramolecular lattice in the stripes while halogen bonds contribute to the connectivity between stripes. To confirm the formation of this strong intramolecular lattice, the estimation of the adsorption energy of a single DBT 
molecule has been performed on a perfect rigid graphene sheet. We are aware of the complete difference between graphene and the $\mathrm{Si}(111)-\mathrm{B}$ surface, however, the complete simulation of $\mathrm{Si}(111)-\mathrm{B}$ is irresolvable using the Gaussian package in a reasonable amount of time. However, we could expect that the $\pi-\pi$ interactions between the DBT molecule and graphene are slightly weaker than MS interaction of DBT on a Si(111)-B surface. ${ }^{9}$ The energy obtained for a single DBT molecule adsorbed on a graphene sheet is relatively low $(-178 \mathrm{meV})$ but still far from $\mathrm{MM}$ interaction of DBT molecules in the elemental cell $(-842.3 \mathrm{meV})$. This difference is due to the three phenyl rings of DBT molecules which are not parallel to the surface, restricting the MS interaction. On the Si(111)-B surface, the same geometrical constraint should also appear leading to MS interaction still lower than MM interaction.

On the basis of STM images and DFT calculations, we can thus assume that the MM interaction, based on hydrogen and halogen bonds, is the driving force which promotes the formation of the DBT/Si(111)-B network.

We demonstrated that the formation of large-scaled $2 \mathrm{D}$ supramolecular networks can be achieved on a silicon surface by using both hydrogen and halogen bond interactions. These interactions are sufficiently strong, as highlighted by DFT calculations, to induce the formation of a compact 2D lattice. We plan to investigate the role of hydrogen and halogen bond interactions to build new architectures on silicon surfaces.

This work was supported by a grant from the Agence National de la Recherche (Nanokan, ANR-11-BS10-004) and a grant from the Pays de Montbéliard Agglomération. Computations have been performed on the supercomputer facilities of the Mésocentre de calcul de Franche-Comté.

\section{Notes and references}

1 J. V. Barth, G. Constantini and K. Kern, Nature, 2005, 437, 671-679. 2 J.-M. Lehn, Supramolecular chemistry: Concepts and Perspectives, Wiley-VCH, Weinheim, 1995.
3 (a) L. Bartels, Nat. Chem., 2010, 2, 87; (b) J. V. Barth, Surf. Sci., 2009, 603, 1533; (c) T. Steiner, Angew. Chem., Int. Ed., 2002, 41, 48; (d) B. Calmettes, S. Nagarajan, A. Gourdon, M. Abel, L. Porte and R. Coratger, Angew. Chem., Int. Ed., 2008, 47, 6994.

4 A. Priimagi, G. Cavallo, P. Metrangolo and G. Resnati, Acc. Chem. Res., 2013, 46, 2686.

5 (a) F. Silly, J. Phys. Chem. C, 2013, 117, 20224; (b) R. Gutzler, C. Fu, A. Dadvand, Y. Hua, J. M. MacLoed, F. Rosei and D. F. Perepichka, Nanoscale, 2012, 4, 5965; (c) Z. Mu, L. Shu, H. Fuchs, M. Mayor and L. Chi, J. Am. Chem. Soc., 2008, 130, 10840; (d) H. F. Lieberman, R. J. Davey and D. M. T. Newsham, Chem. Mater., 2000, 12, 490; (e) P. Politzer, J. S. Murray and T. Clark, Phys. Chem. Chem. Phys., 2010, 12, 7748.

6 (a) K. R. Harikumar, J. C. Polanyi, P. A. Sloan, S. Ayissi and W. A. Hofer, J. Am. Chem. Soc., 2006, 128, 16791; (b) K. R. Harikumar, T. Lim, I. R. McNab, J. C. Polanyi, L. Zotti, S. Ayissi and W. A. Hofer, Nat. Nanotechnol., 2008, 3, 222.

7 (a) Y. Makoudi, F. Palmino, E. Duverger, M. Arab, F. Chérioux, C. Ramseyer, B. Therrien, M. J.-L. Tschan and G. Süss-Fink, Phys. Rev. Lett., 2008, 100, 076405; (b) Y. Makoudi, F. Palmino, M. Arab, E. Duverger and F. Chérioux, J. Am. Chem. Soc., 2008, 130, 6670-6671; (c) B. Baris, V. Luzet, E. Duverger, P. Sonnet, F. Palmino and F. Cherioux, Angew. Chem., Int. Ed., 2011, 50, 4094-4098; (d) Y. Makoudi, B. Baris, J. Jeannoutot, F. Palmino, B. Grandidier and F. Chérioux, ChemPhysChem, 2013, 14, 900-904; (e) B. Baris, J. Jeannoutot, V. Luzet, F. Palmino, A. Rochefort and F. Chérioux, ACS Nano, 2012, 6, 6905-6911; $(f)$ S. R. Wagner, R. R. Lunt and P. Zhang, Phys. Rev. Lett., 2013, 110, 086107.

8 M. J. Frisch, G. W. Trucks, H. B. Schlegel, G. E. Scuseria, M. A. Robb, J. R. Cheeseman, G. Scalmani, V. Barone, B. Mennucci, G. A. Petersson, H. Nakatsuji, M. Caricato, X. Li, H. P. Hratchian, A. F. Izmaylov, J. Bloino, G. Zheng, J. L. Sonnenberg, M. Hada, M. Ehara, K. Toyota, R. Fukuda, J. Hasegawa, M. Ishida, T. Nakajima, Y. Honda, O. Kitao, H. Nakai, T. Vreven, J. A. Montgomery, Jr., J. E. Peralta, F. Ogliaro, M. Bearpark, J. J. Heyd, E. Brothers, K. N. Kudin, V. N. Staroverov, T. Keith, R. Kobayashi, J. Normand, K. Raghavachari, A. Rendell, J. C. Burant, S. S. Iyengar, J. Tomasi, M. Cossi, N. Rega, J. M. Millam, M. Klene, J. E. Knox, J. B. Cross, V. Bakken, C. Adamo, J. Jaramillo, R. Gomperts, R. E. Stratmann, O. Yazyev, A. J. Austin, R. Cammi, C. Pomelli, J. W. Ochterski, R. L. Martin, K. Morokuma, V. G. Zakrzewski, G. A. Voth, P. Salvador, J. J. Dannenberg, S. Dapprich, A. D. Daniels, O. Farkas, J. B. Foresman, J. V. Ortiz, J. Cioslowski and D. J. Fox, Gaussian 09 Revision C.01, Gaussian, Inc., Wallingford, CT, USA, 2010.

9 P. Lazar, F. Karlický, P. Jurečka, M. Kocman, E. Otyepková, K. Šafářová and M. Otyepka, J. Am. Chem. Soc., 2013, 135, 6372. 